University of Louisville

ThinkIR: The University of Louisville's Institutional Repository

Electronic Theses and Dissertations

1937

\title{
Contrast of Plautus and Terence.
}

C. Ruth Ford

University of Louisville

Follow this and additional works at: https://ir.library.louisville.edu/etd

Part of the Classical Literature and Philology Commons

\section{Recommended Citation}

Ford, C. Ruth, "Contrast of Plautus and Terence." (1937). Electronic Theses and Dissertations. Paper 1783. https://doi.org/10.18297/etd/1783

This Master's Thesis is brought to you for free and open access by ThinkIR: The University of Louisville's Institutional Repository. It has been accepted for inclusion in Electronic Theses and Dissertations by an authorized administrator of ThinkIR: The University of Louisville's Institutional Repository. This title appears here courtesy of the author, who has retained all other copyrights. For more information, please contact thinkir@louisville.edu. 


\title{
UNIVERSITY OF LOUISVILLE
}

CONTRAST OF PLAUTUS AND TERENCE

\author{
A Dissertation \\ Submitted to the Faculty \\ of the Graduate School of the University of Loulsville \\ In Partial Fulfillment of the \\ Requirements for the Degree \\ of Master of Arts
}

Department of Ancient Languages

By

C. RUTH FORD -

1937 


\title{
C. RUTH FORD \\ CONTRAST Of PLAUTUS and TERENCE \\ This dissertation was written under the di- rection of the late Dr. John L. Patterson, former Head of the Ancient Language Department and Head of the Graduate School of the University of
} Louisville.

\author{
Approved by: \\ Reading Committee
}

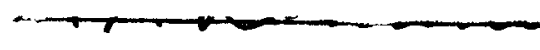

Representative of

English Department 


\section{TABLE OF CONTENTS}

Preface. 0.00 .0 .00 .00 .00 .0 .0 .0 .0 .0 Page

Origin of Comedy ................... I

Beginning of Latin Comedy.....................

Contrast of Plautus and Terence.........25

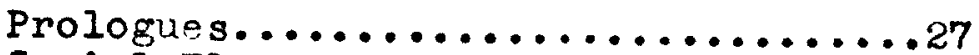

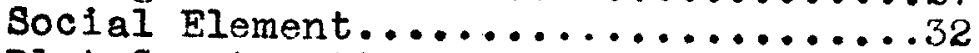

Plot Construction and Development....33

Writing Technique..............52

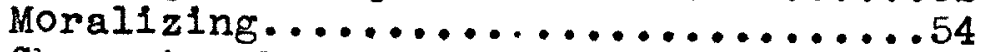

Character Portrayal..............57

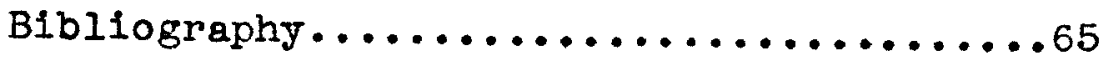




\section{PREFACE}

The contrast of Plautus and Terence in this paper is based on four plays of each writer. The plays of Plautus are Aulularia, Captivi, Menaechmi, and Miles Gloriosus. Those of Terence are Adelphoe, Andria, Hautontimorumenos, and Phormio.

There are three division in the paper. Part One is a historical discussion on the origin of comedy in general. Part Two tells of the origin of Latin comedy. Part Three contrasts the writers on the basis of the plays mentioned.

I am indebted to Edward Capps for his lecture on comedy which proved helpful in the study of the history of comedy.

To the late Dr. John L. Patterson, I owe gratitude for his enduring patience and his willingness at all times to be of assistance to me. 


\section{PART ONE}

THE ORIGIN OF COMEDY 
THE ORIGIN OF COMEDY

To make a study of Plautus and Terence without looking back to the origin of comedy is impossible. Comedy did not begin with the Romans, but was principally of Greek origin. The comedies of Plautus and Terence, in truth, are but translations, or at best, adaptations from Greek originals such as the plays of Menander. The origin of Greek drama, both tragedy and comedy, lay in the performances held in celebration of Dionysus, who was god of nature's productive force. Icaria, or as it was later called, Dionyso, is considered the birthplace of drama. Here Icarus is supposed to have been the first to welcome Dionysus into his home and to have recelved in return for his hospitality the gift of the vine. The people thereafter worshipped Dionysus for the gift. These celebrations in honor of this god form the germ of Greek drama.

Since tragedy was the first type of drama to be developed, it might be well to delve a little into its origin before discussing the

1. Capps, Edward, Greek Literature, p.124 
origin and development of comedy preparatory to contrasting the two Latin writers, Plautus and Terence.

Some authorities credit, and some do not, the belief that these celebrations in honor of Dionysus held both a joyful and a sorrowful element, tragedy developing from the sorrowful and comedy from the joyful. Whatever may be said of this, since there is little difference in early tragedy and comedy, it is commonly accepted that both tragedy and comedy had their beginning with the althyramb, a hymn sung in honor of this god. This hymn described in song and dance incidents from the life of Dionysus. It was acted out by a chorus, members of which disguised themselves as the attendants of the wine-god and were called satyrs, wearing goatskins, with horns, ears, hoofs, and tails. Arion was the first dithyrambic poet of any importance. He wrote about 625 B.C. His real gift to drama was in giving something of regularity to the performance. He set the number of satyrs 
at fifty, a number which was never changed. His chorus members, or satyrs, were sometimes called tragol (goats). W1th order and regularity increasing in the dithyramb, it came to be called satyr-drama, the name being taken from the satyrs (trago1 or goats). Then as actors were introduced, the performances began to be called tragoldia (goat-song) from which the name tragedy is derived. At first only Dionysus was honored. As time progressed, the celebrations began to include more mythological characters. It was at this stage in the development that the name satyr-drama was applied, because with the introduction of herolc legends came a more dramatic element. "Aeschylus (525-456 B.C.) was possibly the first to abandon satyric choreutae and was certainly the first to raise tragedy to the rank of real literature." Even later tragedy writers, however, did not fail to remember the satyric origin of tragedy, and in the celebrations that were given on holldays always presented one satyr-drama in honor of this origin.

1. Fllckinger, Roy C., The Greek Theater and Its Drama, p.2 
Comedy developed from celebrations in honor of Dionysus. About the sixth century B.C., the poet Susarion who came from Megara got together a group of Icarlans and organized the first comic chorus. It was introduced into Athens between 580 and 560 B.C. Official supervision of comedy was not assumed by the state unt1l 486 B.C. at the City Dionysia and about 442 B.C. at the Lenaea. Just as nothing else comes into the world fully grown and fully developed, netther did comedy. It had to go through a stage of growth and development before it was able to stand on its own feet. At first it was not taken seriously since the people already had tragedy to satisfy whatever taste for drama they might have had. Nevertheless, after years of work, comedy took its place at the top.

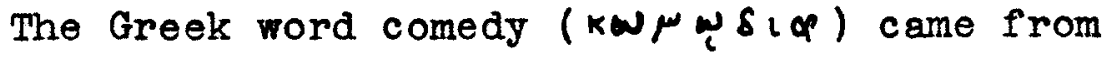
the Greek, comus (kJwos), which denotes a revel and the band of masqueraders who took part in the revel. The comus itself is an anclent celebration.

1. Capps, Edward, op. c1t. p. 124

2. Fllckinger, Roy C., op. clt. p.38

3. Ibid., $p .36$ 
A band of revellers in fantastic masquerades, sometimes as birds, frogs, horses, and the like, would dance and sing at the winter festival of Dionysus, when the new wine was opened for the first time. There were several ways in which these reveliers carried on their entertalnment. As they would come on the stage, a leader might address the bystanders. Then the masqueraders, divided into half choruses, would sing songs alternately with speeches chanted by the leaders. At the end of the performances a flute player would lead the group off the stage. Often the comus consisted of a company of players marching from one house to another, dancing and singing at each place to the accompaniment of a flute player. Two elements might be seen in the comus-- an invocation to the gods to attend the worshippers in their celebration, and an element of obscene revelry which often took the form of satire addressed against individuals.

In connection with the comus being used as a celebration in honor of Dionysus, something more might be sald concerning these fostivals

1. Flickinger, Roy C., op. cit. p.37 
before proceeding with the development of comedy. There were four well known festivals of Dionysus-Country Dionysia, Clty Dionysia, Dionysia of the Flowers, and Dionysia of the Wine Press (Lenaea). The two important ones in connection with the development were the C1ty Dionysia and the Lenaea, and the attendance was usually very large. Such celebrations, which were partially of an obscene nature, coupled with the dancing, reveling, and drunkenness, usually resulted in the birth of many 1llegitimate children. This is mentioned here because the children born as a result of such revelling were often the subject matter of New Comedy poets whom we shall discuss later. Nevertheless, the crowd never lost sight of the fact that the celebration was a religious one. Even though much of the subject matter for the festivals came from Greek mythology, this did not prevent them from treating the divinities with the utmost disrespect. Even Dionysus, the patron diety of these festivals, is represented by Aristophanes in 1

Frogs as cowardly and lustful, being beaten with

1. One of the greatest translations ever made was by Hookam Frere. 
many stripes before the very eyes of his worshipers. The chorus of the old Attic comedy, conslsting of twenty-four members, unquestionably developed out of this ancient Dionysus comus. Aristopanes' works have the same characteristics of this primitive comus-masquerading with animal masks, singing and dancing, addressing the spectators, alternation of speeches by the leaders with songs by the half-choruses, and finally the gay procession. Tragedy may have influenced comedy in the prologue and in the choruses which separate the episodes, but the part of the play which comes between the prologue and the end of parabasis and likewise the merry revel at the end is peculiarly comedy, owing its origin to nothing other than the old comus. The plot of a play during the period of Aristophanes was very simple. Usually two opposing principles were represented by two conflicting elements. The prologue explains the situation of the players. One group will endeavor to carry out a plan suggested by one of the actors. Just as they are making some progress toward accomplishing their purpose, the opposite side interrupts by some means. This usually comes about when the chorus enters, bringing the two conflicting forces into direct line of battle 
with each other. Both word battles and fist fights ensue, the members of the chorus becoming so interested that they even take part in the battle. A short lapse in action follows this outburst. After the question has been put forth, a lively debate follows with jokes and jests thrown in by a third party who acts as a clown. With the decision finally being rendered for one side or the other, we have the real end of the play (catastrophe), for the part which follows is, in reality, not connected with the plot of the play. The parabasis comes next with all the actors departing from the stage, leaving the chorus to come forward and address the spectators. The parabasis is divided into two parts. In the first part the leader of the chorus unmasks and comes forward to speak about the poet. He tells of his life, accomplishments, and standing with his rivals. The second part of the parabasis brings a recurrence of the balanced structure which was present in the debate. The two half-choruses alternately sing lyrics with recitations thrown in by the leaders. Masks are worn during this second part of the parabasis. This is followed by short 
eplsodes also unnecessary for the sake of the plot. The purpose of this is to explain to the audience the advantages gained by the victorious side. This is done by means of one of the actors being placed on the stage where he can easily address the spectators and still speak to various actors who come on the stage for one reason or another. Dorlan Comedy can be accredited with that part of the play which follows the parabasis. In speaking of Dorian Comedy, Epicharmus, whom Plato called the "prince of comedy," is the person thought of. Epicharmus wrote around 500 B.C. He had really gained popularity and fame before the time that comedy was offlcially recognized by the state. When in 485 B.C. his home, Hyblaean Megara, was destroyed, Epicharmus moved to Syracuse where he met Aschylus through whom the knowledge of his achlevement in comedy came to Athens. Dorian comedy, though somewhat similar to Attic comedy, had a distinct influence on what is usually considered distinctly Greek comedy. Masks were used, but

1. Capps, Bdward, op. c1t. p. 128

2. Ibid., p.131 ff. 
instead of representing animals, they masqueraded as goblin-like creatures. They worshipped Dlonysus as the god of fertility. Comlc sketches taken from everyday Iife were also introduced. In Megara, the home of the poet Susarion who was mentioned as the first to introduce choric comedy, some kind of dramatic form was given to these celebrations. About the sixth century, during the regime of the democracy, political satire was brought into the plays. It was in southern Italy and sicily where the celebrations came under Dorlan influence that they began to take on something of a literary nature. Eplcharmus had as a background for his work the Dionyslan celebrations of Peloponneseus and the mythological works of southern Italy. Although he was Influenced by the celebrations in honor of Dionysus, his works were no longer associated with this god. He gave stage performances portraying mythological characters and deeds, and scenes from daily life. He also introduced typical characters such as the parasite, the drunkard, and the soldier. His great gift to the fleld of comedy--an important gift at such an early date--was his transformation 
of loosely connected ribald scenes into a whose which had at least some suggestion of artistic and Itterary form. He organized his subject matter so that his play progressed from one scene to another. Unlike the Attic comedy, these Sicilian plays had no chorus. The goblin-like creatures which correspond to the masqueraders of Attic comedy were not organized into a group. His plays consisted of a series of episodes separated by dancing of individual actors, not choruses. If the plot consisted of conflicting elements, a debate between the actors without a chorus entering in settled the matter. It may be concluded, then, that Attic comedy at the time of Arlstophanes took 1ts choral element from the Attic comus, its balanced structure with chorus responding to chorus and leader from Attic influence, and the loosely connected parts following the parabasis from Dorian comedy. Only by dropping some of the frank indecency of this early comedy and by dolng away with such a loosely connected structure, was it made possible for a form of literature which might be of permanent value to 
develop out of the old Attic comedy. At first these performances were given by volunteers under no authority of the State. After 486 B.C., when they came under the official jurisdiction of the State, they grew in importance and improved in form and structure. When in 442 B.C. comedy was admitted to the January festival, the Lenaea, it became possible to double the number of plays given each year to make the total ten. This number remained the same with perhaps a change now and then for the next three centuries. Now that comedy had started to grow it did not cease, but grew in response to the social and political changes which must inevitably come about in every country, especially in a country which had such leaders as Greece had from the age of Pericles to Alexander the Great. Greek comedy may rightly be divided into three groups or classes--0ld Comedy, Middle Comedy, and New Comedy.

old Comedy is thought of as that of the period from the beginning down to Aristophanes, or shortly after the close of the fourth century. Political

1. Flickinger, Roy C., op. c1t. p.39 
satire and ribald jokes concerning individuals were the chlef materials for subject matter. Comedy, unlike tragedy, was not limited to the use of mythology as subject matter, but drew upon any subject which might give opportunity for lampooning. As already mentioned, the poets had no scruples against ridiculing the gods and used this as a great part of their basic material for plays. This old Comedy is really the Attic Comedy already discussed, with the chorus in disguise and with the same structure. Sometimes the poet drew upon his imagination and pictured some strange land where everything was perfect--In short, a Utopla. The one outstanding characteristic that distinguishes it from any other class is that the poet never fails to stand in judgment upon the rest of the world; he employs political satire, severe jests against individuals, ridicule against the gods, but he himself is always the critic. The extreme democratic spirit of the age of Pericles alded the poets in this. They had absolute freedom of speech, and certainly made use of it. The people 
wanted what the poets were giving them because the poet had enough understanding of human nature to realize what it was they wanted. They wanted satire addressed against the person in the public eye. The poet gave them this in the way of political and personal satire. The poet's business was to entertain, but to entertain with satire. Aristophanes, the poet who is really the exemplification of the spirit of his day, aptly expresses the wish of the comic poet of his age--"to have caused little vexation and given much pleasure." The plays of Arlstophanes are simple dramatic performances. They show the spirit of the day in bringing before the eyes of the audience not only typical characters such as the cook, the soldier, the parasite, etc,, but also real people such as Euripides and Socrates, and ridiculing them. This poet, the greatest writer of old Comedy, was first and foremost a "fun-maker."

The second period, Middle Comedy, was really nothing more than a transition period between 01d and New Comedy. It lasted about fifty years. This transition period developed no great poets

1. Capps, Edward, op. cit., p. 140 
with particular characteristics belonging only to this period. It was more a time when the necessary changes to suit the development in politics and social life must be made in comedy. Fltherto all the poets had been interested in a certain rude structure which gave opportunity for the writers to ridicule. Now they began to be more interested in plot development. The chorus played an increasingly less important part, unt1l by the end of this fifty years, it had no active part in the play, but became merely an interlude. As the chorus disappeared, the balanced structure brought about by the part of the two half-choruses with their leaders had to be dropped. The plays came to consist of episodes or acts divided into scenes, with each adding its part to the solution of the plot. They were more like the Dorlan plays of Eplcharmus. Of course, social and political life influenced the writing a great deal. With the disappearance of the extreme spirit of democracy as a result of the Peloponnesian War, and with the overthrow of Athenian freedom by Alexander and the coming in of a more refined society, the people no longer 
cared for the obscene jests of old Comedy addressed aginst individuals, but wanted a more generalized plot which would depict human traits in general. Disguises also were dropped. More and more, typical characters were introduced. The parasite, the blustering soldier, and the loyal slave were favorites. Again the deeds of the gods, their lives, loves, marriages, etc., became a much loved topic. With these gods portrayIng traits of human beings, Middle Comedy might be looked upon as the span which led from an Individualized satiric comedy to a more generalized humanistic one. The storles of the gods served their part in representing characterlstics of human beings. Having served this part, these mythological beings once again lost their important place in comedy. They were represented in New Comedy some but not as main characters--merely as minor ones to explain something that was happening.

With the advent of New Comedy, the poets came closer and closer to human nature. Their plays were written about such people as lived then. 
Their interest became more concerned with plot, the development of plot, climax, and the outcome. The people were interested in the plays because they were written about them. They could laugh, cry, or be 111 at ease about the outcome of a situation, because it was a situation in which they might $f$ ind themselves. Whenever human nature is dealt with in plays, the element of love enters in. Hitherto, love had played little or no part in comedies, because hitherto the plays had not been written about life. Now into every play was woven a love story, sometimes not very elevating, it is true, but nevertheless, a love story. Someone would object to the union, but finally the two lovers would be brought together, the loyal and good traits of each one being praised by the poet. Unlike the plays of today, the love scenes were never acted on the stage. The audience heard of them through the words of some actor, either the boy concerned, or, very often, his slave. The interests of the spectators lay not so much in the persons involved as in the outcome of the 
situation.

Menander is the poet who exemplifies the spirit of New Comedy. His first plays were written when he was eighteen years of age, in 324 B.C., a year before the death of Alexander the Great. In his thirty three years of writing, unt1l his death in 291 B.C., he wrote one hundred plays. He was an educated man, having studied phllosophy and rhetoric, and was also a person of high culture. He was a keen observer of human nature, studying people for himself and not relying upon some one else to tell him what people were like and what they liked. This trait was probably the greatest help of all in gaining his success. With what had already been done in the field of comedy as a background, and wh the educational and cultural background he had bullt for himself, there is no wonder that Menander was able to write plays that stood out above all others in structure, plot, and portrayal of human nature, and which the Latin writers, Plautus and Terence, deemed worthy of their attention. 
PART TWO

THE BEGINNING OF LATIN COMEDY 


\section{BEGINNING OF LATIN COMEDY}

Since the origin and development of comedy among the Greeks has al ready been discussed, there is little that can be sald concerning this subject among the Romans, as most of the Latin comedy was translated or adapted from Greek originals. There is an element of Italian origin which might be mentioned since it began with celebrations at country festivals just as the Greek did. Before Greek influence touched Latin drama, there were four types of representations given by the Italians. These were the versus Fescennini, the satura, the mimus, and the fabula Atellana. The first of these, versus Fescennini, named from Fescennium, a village in Etrurla where they were presented, consisted of songs and dances with perhaps some coarse comic dialogue. The saturae were songs acted out by the country boys of Latium. They enacted scenes from daily life, but still there was no connected plot. Even after regular plays were given, the saturae were presented

1. Terence, The Adelphae, p. IX 
as farces after the regular performances. Then they were called exodia.

The mimus was a crude farce of a low type. The subjects for representation were taken from the low life of the town. They were especially known for their obscentty and appealed to the type of people who would have been unable to appreclate a better drama. The sansual appeal was accentuated by the introduction of women as players. Of course, the women were of a low type.

The fabulae Atellanae, so called from the Campanian town, Atella, where they were at first presented, were the best of these early Italian representations. They were more dramatic in form. The players wore masks and depicted scenes from daily country life, using stock characters. They were usually the sons of well-to-do c1tizens, independent of anypoet. They did not write out the dialogue. After the introduction of Greek comedy, these productions were also used as exodia.

It would seem that Roman drama would have grown out of these beglnnings just as Greek drama 
did out of the Dionysalc celebrations. But the Roman people were not of the same nature. The Greeks enjoyed hearing satire addressed against famous men of the State and it was with the introduction of this element that Greek drama began to take on the form of plays instead of mere singing and dancing by choruses in celebration of the god Dionysus. Such satire in Rome would have been rewarded by the writer's or actor's being severely punished by the magistrates. Romans were interested in increasing the power of their state, in making laws, and in creating good officials. Drama, at that time, seemed to them something which should interest only the low type of people. Possibly this was due to the fact that such presentations as they had had were of a low type. After the conquest of Pyrrhus in 274 B.C., and the final conquest of Magne Graecia, and finally after the first Punic War when Greek slaves and refugees began to pour into Rome, the seed was planted for Greek drama also to come to Rome. And thus it is from the Greeks that Rome got its real drama. 
Livius Andronicus, a native of the Campanian town, Tarentum, came to Rome as a slave. He later became a schoolmaster and actor, and is considered the first Roman playwright. His first works really consisted of nothing more than a recitation given off stage while he himself acted it out before the audience. Then he introduced dialogue into his works and later added actors, therefore presenting real plays. His plays were influenced by both the Italian elements and the Greek New Comedy, although 1t would, seem that the Greek element held first place. In 240 B.C. he translated and brought before the Romans for the first time a Greek drama. The plays which were mere translations, with the actors wearing the dress of the Greeks and the allusions being made to Greek customs were called fabulae palliatae. The plays which were based on Greek plots but were adapted to Rome with the actors wearing Roman dress and allusions beling made to Roman customs were called fabulae togatae. The second writer of any note was $C n$. Naevius, a native of Campania. He presented plays about 235 B.C.

1. Simcox, George A., A History of Latin Literature, Vol. I, p. 19 
He made a grave mistake in not following the trends of New Comedy. He patterned his works on 01d Comedy, especially on the plays of Aristophanes, and wrote about some of the leading statesmen of Rome. The Romans did not care for literature of this type. Drama written about everyday occurrences with the purpose of entertaining was all right. But to write something which might tend to hurt the Republic was something different. Naevius was thrown into prison. When he was released, instead of profiting by his mistake, he did the same thing again, and, as a result, was exiled in 205 B.C.

The next writers of importance are the two concerning whom this study is made--Plautus, the greatest Roman comedian, and his successor, Terence. Before I contrast these two men through a study of their works, it might be well to consider the occasion of presenting the plays in Rome. The Greek plays had been presented on days when celebrations were given in honor of Dionysus and other gods. The number of holidays among the Greeks.was not so great as among the Romans. Therefore there was more occasion to present plays at Rome. 
Festivals at Greece had been held in honor of the gods. In Rome, they were held not only in honor of gods, but were sponsored also by magistrates and other statesmen who wished to gain favor, were given at funerals of famous citizens and for almost any other excuse. The main festivals were the Ludi Megalenses (April 4-9), Lud1 Apollinares (July 6), Iudi Romani (September 4-12), and the Lud1 Plebeil (November 16-18).

This discussion will be based on four plays of Plautus and four of Terence, those of Plautus being Miles Gloriosus, Captivi, Aulularia, and Menaechm1, those of Terence being Heautontimorumenos, Andr1a, Phormio, and Adelphi.

I. Plautus, T. Maccus, Menaechmi, p.19 
PART THREE

CONTRAST OF PLAUTUS AND TERENCE 


\section{CONTRAST OF PLAUTUS AND TERENCE}

Titus Maccius Plautus, acclalmed by many Rome's greatest comedy writer, was born in 254 B.C. in north central Italy, (Umbria). Little is known of his early life. He is said to have accumulated quite a sum of money as a stage carfenter. This, however, was lost in a bad investment. His next work was in a mill, where by working the treadmill, he is thought to have'caused the deformity of his feet from which he gained the name, Plautus, Flat-foot. others say that he was born with this deformity. Probably through his work around the stage, he became interested in play writing. His literary career began about 224B.C. and lasted for forty years until his death in 184 B.C. The plays of Plautus were written for the people. Although they were based on Greek plays, those of Menander in particular, he did not hesitate to "Romanize" them by bringing in Roman customs, Roman laws, Roman characteristics, or referring to the Greeks as barbarl. This character1stic will be brought out more clearly in the discussion of the plays. Let it suffice to say here that at all 
times he endeavored to give the people what they wanted.

His successor, Publius Terentius Afer, born just a year before the death of Plautus, appears to be more refined in his writings. He was a native of Africa (hence the name Afer), and had come to Rome as a slave of $\mathrm{M}$. Terentius Lucanus, who educated him and later gave him his freedom. The name Terentius was taken from his master. Terence seems to have gained frlendship with such influential people as Sciplo and Laelius, and we find in his prologues that he continually defenids himself against the "maledictis" of others who criticize him severely, saying that it is only through his friends that he is able to gain any popularity as a playwright. Terence followed more closely than did Plautus the plays of Menander. That is, Terence's plays were more truly translations. He did not introduce Roman ideas fust for the pleasure of the people. H1s plays were written more for the ilterary circle of which Scipio and Laelius were members, than for the mass of the Roman people. 
In looking at the plays themselves, we find that the first great difference between Plautus and Terence is the use each makes of his prologues. It must be stated that there is no certainty as to whether the prologues of Plautus are original with the exception of those of Aulularia, Rudens, and Trinummus.

Consider these four plays of Plautus,-- Menaechm1, Captiv1, Aulularia, and Miles Gloriosus. In each one the speaker first asks that the audience recelve Plautus favorably, then gives the entire plot, and finally seeks the attention of the audience. This is true even of Miles Gloriosus, where he does not give the prologue until the second act. The first act of this play is concerned with introducing to the audience the type of man the captain is. One characteristic of Plautus found often in his prologues, though not limited to this part of the play, is that he does not hesitate in his play to pause in the regular lines and to address the audience or even any one person in the audience. An example of this may be found in the prologue to Captivi, lines 11-14.

1. Plautus, T. Maccus, Menarchm1, p. 119 
in accedito.

Si non ubi seders locus est, est ubi ambules

quando histrionem cog1: mendicarler. ego me tua caussa, ne erres, non rupturu' sum."

"Come nearer. If there is not a place to sit, you may walk. Since you make an actor beg you (not to cause disturbance), I'll not burst myself (my lungs) for your sake."

On the other hand, Terence, in his prologue to Andria, Hautontimorumenos, Adelphl, and Phormio, does not in any instance give the plot. This is one example which mlght prove that Plautus was writIng for the people, Terence for a favored few. Plautus gave the plot so that the people could better understand what was to take place. They were not intellectually so great as the audience of Terence. Terence withheld the plot and made his plays more like literary works which might be read with some degree of enfoyment, at least, in wondering that the outcome might be. In the prologue of each play mentioned above, Terence defends himself against the "malevoll veteris poetae maledictis", Andria, 1.6-7 "the slanders of a malevolent old poet," a contemporary comic poet, Luscus Lavinius, who critic- 
ized him for using plots of Greek plays and for relying upon the help of friends. Terence answers both these accusations. In the prologue to the Adelphi, he explains clearly that he took his plot from a part of a Greek play which Plautus failed to use in translating and adapting the play. Then, in answer to the part of the criticism referring to his friends, he does not deny that he recelved assistance from them, but says, rather, that he considers it the "laudem-maxumam" that he should be able to please such renowned men who are known to all Rome. of course, each prologue ends, as did Plautus', with a petition to the audience for attention. In addition to these elements in the prologues, Terence brings out one of the characteristics of his writing in his prologue to Hautontimorumenos. In 1.46 we find these words--"In hac est pura oratio". Prof. E. S. Shuckburgh translated this--"In this play the attraction is purfty of style." He goes on to say in his note on this line that Ambivius, the speaker of the prologue, is contrasting the bustling, stirring plays in which he has often acted with the quiet and more refined drama of this play, where the 
beauty of style and language is the main feature. In this, Terence again differs from Plautus, because Plautus' plays seem to be more sulted to action and less to mere reading than those of Terence. This can be easily proved by reference to the Menaechmi. Even though the Menaechmus who had just arrived at Epidammus had came to this place in quest of his twin brother, he never seemed to suspect that this person people were constantly confusing him with might be this twin brother. This seems a little far fetched, and certainly a play built on such a plot makes fit material only for acting, not for mere reading. The Romans derived pleasure, in all probability, from the trouble these mixed identities caused, and did not bother to think that the plot was very weak. Plautus knew that they wanted just such plays and gave them to the people.

The plays themselves cannot be disposed of so easily as the prologues. Both Plautus and Terence used Greek plays as a basis for their works, Menander being the writer who was favored. These Greek plays vere translated into Latin and, particularly in the case of Plautus, adapted to the tastes of the Roman people. The plays were called comoediae palliatae 
since they were presented basically as Greek plays and the actors were present ed as Greek characters. The themes and characters were generally very similar, but they were treated in quite a different manner. Often a young man fell in love with a girl supposed to be the property of a procurer. Through the help of a slave falthful to the young man involved, the angered father was swindled out of the money needed to buy the girl. Of course, various complications often occurred in the dealings the slave had to make. The complications are similar to those of the Attic plays where two elements representing conflicting principles were concerned and always, just as one side was progressing with plans, the other would enter in and offer opposition. The opposition in the plays of Plautus and Terence usually fresented itself when the father found out that his son was involved with a girl not of his cholce. This brought on additional work for the slave because he had to keep the old man in 1gnorance as to the facts of the case and also had to keep the youth pacified. In the end the slave would be successful in outwitting the father, the girl was found to be of Athenian birth and an excellent match for the boy, and all turned out weil for everyone concerned, the faithful slave 
recelving his freedom as a reward for his endeavors. Often a parasite entered in to help swindle the old man. In this case, the parasite and the slave usually worked together, the slave, however, keeplng the young master's Interest at heart, the parasite, thinking about the dinner he would get out of the affalr. Both playwrights had as stock characters the idle rich son, the crabby old man, the slave faithrul to the son, the courtesan or joung wife, and the parasite. There were others who came in some of the plays, but these were the most prominent. The difference, then, in Plautus and Terence came not in the characters or the theme, but in the handing of these characters and in the development of the theme.

First, it must be remembered that Plautus and Terence wrote in different ages and for different types of people. Plautus was only the third comedy writer of any note in Rome. The public had not jet been educated to comedy. In the middle of a play the entire audience might leave for a gladiatorial contest if the entertalnment did not prove interesting enough. For that reason Plautus had to introduce farce into his plays. By the time Terence wrote, while it is true that the situation had not changed 
altogether, drama had a little surer foothold among the Romans. Furthermore, Terence did not write, as ald Plautus, for the general public, but for a group of educated men known as the Sclplonic Clrcle. Thetr tastes in literature were not to be compared with those of the Roman public as a whole. That Terence was able to please such men as these is a fact which must be attributed to his higher education.

It has been mentioned that the general theme for both writers was the same. Let us note, then, the difference in plot construction and development. With Plautus, plot was not the main interest but merely served as something around which he could bulld a story so that he might have an excuse for the crude jokes with which he entertalned his public. As a result, his plots were very thin. It was not his purpose to make the audience wonder what might be the outcome of the play, but to make them laugh by means of farce. The weakness of his plot has already been 1llustrated by the story of the Menaechmi. Another instance can be found in his Captivi. The whole story centers about the fact that an old man, Heglo, has a son who was captured in war. In an endeavor to get his son back, he buys all the captives 
he can in expectation of getting one worthy of trade for his son. Moreover, as the story progresses, it is disclosed that he already knows who has his son and how to get in contact with the man. It is ridiculous to suppose that anyone could be so foolish as to use such methods to regain a lost son. The plot, however weak it might be, served Plautus, nevertheless, In that it gave him an opportunity to give his spectators what they wanted--crude jokes.

The same weakness of plot might be illustrated by Aulularia and Miles Gloriosus.

Detelopment of plot can hardly be spoken of in connection with Plautus. He merely presented the facts as they occurred. Even with this presentation of events in a chronological order, he might have produced some dramatic action if it had not been for the fact that he thought nothing of interrupting his action at any time. As has been stated, main purpose in writing was to entertain with jokes. If opportunity to insert a joke presented 1tself, Plautus took advantage of it even though development of a scene vere temporarliy interrupted. An example of this is found In the Menaechmi, when Cylindrus, the slave, mistakes the twin brother from away for the twin brother of 
Epldamus, who had promised to entertain a parasite named Peniculus. In the midst of the confusion concerning the ldentity of the twins, Plautus pauses to play on the word peniculus, which means "brush." When Cylindrus remarks that he has the food for the parasite, this Menaechmus, of course, knows nothing whatsoever about 1t. Cylindrus, then, inquires about Penfculus, meaning the parasite. Menaechmus' slave answers (1. 286) "Eccum in vidulo saluom fero," translated, "I carry it safe in my wallet"--referring to a brush.

Again, in Miles Gloriosus, he has the lover, Pleusicles, make a pun on a word when the reader of the play should be in doubt as to whether or not Pleusicles will be able to get his sweetheart away safely. Pleuslcles has come dressed as a sallor on pretense of taking the girl to her mother who is ready to leave on a boat. Over one eye he wears a guard. When questioned about his eye, he answers (1. 1309)

"Amoris causa hercle hoc ego oculo utar minus. Nam si abstinuissem amorem tamquam hoc uterer."

"On account of the sea, I use this one eye less. If I had stayed away from the sea, (amore-from love), I should have used this the same as the other." 
Plautus' method of introducing characters on the scene is another weakness in the progress of his play. He does not have them make natural entrances and exits as a person actualiy does in life. One of his characters might be in the middle of a conversation with another, when suddenly he will stop speaking to say, "Ah, I hear the door creaking. Someone is coming out." With a little effort he could have made this entrance natural by leading up to the entrance of this particular person. Examples of this are numerous. A few follow:

$$
\text { Mlies Gloriosus- (1. 528) Periploctemus has }
$$
been pleading with Philocomasium to hurry to his house. In the midst of his entreaties, he says, "aperitur forls"--"the door is opening" whereupon out walks sceledrus, who adds nothing to that particular scene.

Menaechmus- (1. 523) Menaechmus is somewhat disturbed because everyone he meets says things about him which he does not understand. As he is complaining about this particular situation, he pauses to say. "sed concrepuit ostium"--"but the door is opening." 
If Plautus had occasionally employed this method of bringing in his characters when an entrance of a particular character would have meant something to the actor on the stage, it would not have been so bad, but he used this as a means to introduce nearly every actor on the stage.

The improbability of many of the happenings in his plays is another weakness of Plautus as a playwright. Because the scenes had to be acted in the street, he should have taken additional caution to overcome this difficulty instead of seemingly having this as an excuse for the improbable to happen. In his Aulularla, knowing that Euclio is so miserly, one could never expect the man to bawl out in the street where everyone could overhear him (1. 580-86)

"edepol ne tu, aula, multos inimicos habes atque istuc aurum quod tibi concreditum est. Nunc hoc minl factust optumum, ut ted auferam, aula, in Fidei fanum:

Fides, novisti me et ego te: cave sis tibi ne tu immutassis nomen, si hoc concreduo. ibo ad te fretus tus, Fides, fiducia."

"Vessel, you and this gold which I entrust to you have many enemies. Now it is best that I place this(gold) with you, vessel, in the holy place of Faith. Faith, you know me and I you. Take care that you do not change (your name) if I trust you. I shall go, Falth, relying upon your trustworthiness." 
of course, Euclio's speech to Falth was overheard by the slave of Lycldes and this led to the theft of his gold. Plautus could have brought about the stealing of this gold without making the way of the theft so obvious. Perhaps here again he was pleasing the Roman people in using the temple of Falth, which represented a holy place, as the means through which something wrong was done.

Another Improbability occurs in Miles Gloriosus when schemers planned to fool the captain by pretending that the woman who, they said, was the wife of Perlploctemus, had fallen in love with him, thus giving his mistress a chance to leave with her lover. If the captain and Periploctemus were, nolghbors as Plautus pictured them, why would the captain not have known that his nelghbor was unmarried? or if someone had told him that the two had just recently marrled, it is not probable to suppose that such a new bride would be interested in anyone else to the extent that she would go out and look for him. The Improbability of the whole plot of Menaechmi has already been mentioned. 
One more example is found in Captivi, where Hegio, heartbroken over his son, stops to joke with Ergasilius about eating. Plautus introduces such a scene because the parasite was a favorite character among the Romans and he knew this diversion from the story would please the spectators more than an old man's tale of woe about his lost son.

Plautus disregards consistency. He has translated Greek plays, used basically Greek scenes and characters, and yet, time and again, he alludes to Roman laws, customs, etc. Perhaps he can be excused on the basis that he was entertaining the Roman public, a public that he was none too sure of, and he thought that if he used Roman allusions, he could better hold the attention of his audience. But if that is true, he should have been consistent to the entent that all allusions to laws and customs were Roman, and not some Roman and some Greek. Several examples of this inconsistency can be cited: Menaechm1 - (1. 587)" aut ad populum aut in jure ad iudicem rest" "Before the people or at law or before a judge the case lies." 
This is a reference to the three types of legal cases tried at Rome.

In Captivi, (1.489) he refers to the Velabrum which is a district in Rome between the vicus Tuscus and the forum boarium (cattle market).

The Miles Glorlosus contains many Roman allusions. In IIne 592 he speaks of "senatum," which is a Roman body. In line 1064 he uses the word "modiorum" from "modius"--a dry messure among the Romans corresponding to a peck in our measurement.

His lack of consistency is especially shown by the fact that in the same play in which he uses Roman allusions he also uses Greek ones, writing as if the play were a purely Greek play fust as 1t was originally. In line 880 in Captivi when Ergasilius Is swearing by Roman towns, Plautus has Hegio ask (1. 883)

$$
\begin{aligned}
& \text { "quid tu per barbaricas urbls luras?" } \\
& \text { "Why are you swearing by forelgn towns" }
\end{aligned}
$$
meaning that Roman towns are forelgn ones.

1. Ad populum refers to criminal cases. In iure refers to civil cases settled by a magistrate giving judgments on points of law when the facts.were not disputed. Ad ludicem refers to civil cases where the facts were disputed and then referred by the magistrate to an unofficial arbitrator who gave judgment . Cf. Plautus, Titus M., Menaechmi, p. 161 
In Miles Gloriosus, line 727, he mentions "agnoranomus," which is a Greek market Inspector. Finaliy, in regard to construction Plautus did not have his players act as if they were characters in real life. They would address members of the audience, showing by this that they were just acting parts in a play which was being observed by spectators. In the Menaechm1 (1.880), he has Menaechmus say to the audience,

"vosque omnis quaeso, si senex revenerit, ni me indicetis qua platea hine sufugerim"

"And I beg all of you, if the old man returns, not to tell him by what street I have fled."

In Aulularia, Euclio calls upon different members of the audience to help him stop the slave of Ijcides who has escaped with his gold (1. $715 \mathrm{ff.}$ ).

Since a number of bad qualities and some bad scenes of Plautus' have been mentioned, it would be unfalr to leave this part of the discussion without referring to one or two scenes which are exceptionaliy good. An outstanding example is found in Aulularia, (Iine $733 \mathrm{ff.}$ ) where Euclio is talking with Lycides. Lycides admits that he is guilty of the wrong of which Euclio is complaining, thinking that Euclio is angered about his daughter's being wronged. In reality, Euclio is worrying about his lost gold. Both avold naming 
the object of the discussion for some time, and some interesting bits of conversation result. Another good scene is found in Miles Gloriosus (1. $411 \mathrm{ff.}$ ) where Philocomasium fools the captain's slave, Sceledrus, by passing through a secret passage to the house across the street and playing the part of her owa twin sister. Many amusing incidents come out of this deception, probably the most interesting being the perplexity of sceledrus.

In concluding these remarks about plot construction and development in Plautus, it may be sald that his plays were scenes thrown together not as a perfect whole but just in a chronological order, that his sole purpose was to entertain with jokes, and that he was inconsistent.

On the other hand, let us look at plot construction and development in Terence. Here one finds a very different story. One feels almost as if he had stepped from a vaudeville show into a drama. While Plautus made no effort to develop a plausible plot, Terence carefully brings out a dual plot in each play. The same thing he says of his characters might be said of his plays. Phormio (1. 267) "tradunt operas mutuas"--"They mutually help each other." This dual plot of Terence does not consist of one main plot with a sub-plot, but really of two plots of equal importance, and, with one exception, 
the Adelphi, each is needed to bring about the other. The dual plot in this play is not so well developed as in his other plays bcause the second plot is really not essential to the development of the play although Terence uses it in that way. The first plot in Andria consists of the story revolving about Pamphilus' promise to his father to marry Chremes' daughtor because he knows he will be refused. The second plot involves the lover, Charinus, who worries about Pamphilus' marrying Philumena. The first of these two plots offers an interesting affair which is handled rather well. The disturbance of Pamphilus, when Chremes promises Simo that Pamphilus can have his daughter, and the means by which they try to avold the match prove entertaining. Even this has its weak points in that Davus, the slave, bustles about throughout the play and accomplishes absolutely nothing. Terence must have intended Davus to be a typical slave helping the young man, but, as it happens, the incldents in the play which bring about the good results all have occurred whout any aid from Davus.

The second plot in the Andria has been the source of much discussion. Donatus says that the characters, Charinus and Byrrhis, were not in the original play by Menander but were Introduced into this play by 
Terence so that Chremes' daughter, Philomena, would have some one to marry when Pamphilus married the girl he loved. But Terence need not be criticized for providing for Philumena in this way. Certainly such provision far excels the way he handles Bacchls in his Heautontimorumenos when he has her suddenly dropped from the play without mentioning what became of her, and the young man marries some one not hitherto mentioned in the play. It seems that it is not in the introduction that the fault lies but in the manipulation. He falls to make the new characters interesting because, from the beginning, he leaves no doubt either in the minds of the spectators or in that of Charinus as to Pamphilus' attltude toward Philumena. Even when Byrrhia overhears Pamphilus telling Davus he will agree to marry Philumena and Byrrhia goes immediately to h1s master with this starting bit of news, Terence does not bring about any complication of love interest, because Charinus, upon asking Pamphilus about the affair, learns that the agreement is merely part of a plot to fool the old man. Thus, his

1. Norwood, Gilbert, Plautus and Terence, p. 146. 
worrles are over, and, incidently, this second plot is rather weak.

Heautontimorumenos also has a two-fold plot. In the prologue Terence says that he has taken the simple plot of a play of Menander and made a twofold play out of 1t. The two plots, one involving Clinia, his father, Menedemus, and his sweetheart, Antiphila, the other, clitipho, his father, Chremes, and the courtesan, Bacchis, are of equal importance, and each helps to solve the other. The weakness in this play has been suggested above--the dismissal of Bacchis from the play without any provision being made for her. The plot is rather complicated. It is difficult to imagine an audience of Plautus' following such a story even if it were explained first in the prologue.

The Phormio, a later play has a dual plot which is less subject to criticism. The plots rely upon each other for solution, both revolving about the parasite Phormio. Chremes wishes his nephew, Antipho, to marry a daughter of his by a second wife unknown to his friends and wife at Athens. His son, Phaedria, is in love with a music girl. While Chremes and Demipho, father of Antipho, are away, Antipho marries 
a girl who later turns out to be the daughter of his uncle. The old men, upon returning from their journey, learn this news, and not realizing that she is the right girl, offer Phormio money to take her back, because he had acted as her guardian in order to bring about the legality of the marriage. This money goes to buy Phaedria's mistress. When the old men learn that Antipho has married the right girl, they try to get the money back, and in so doing anger the parasite, whereupon he tells Chremes wife that her husband is a bigamist. Through this Phaedria is permitted to keep his mistress, since his father, being a bigamist, has no right to reprove him. The love affair of Antlpho forms the nucleus of one plot in this play and that of Phaedria, the other. The way the two ald each other shows that Terence's skill in the dual-plot method has improved. The money paid to free the girl in the one plot is used to buy the girl in the other. Thus the two are closely interwoven by the scheming of Phormio.

The two plots of the Adelphi are not so closely interwoven. The same characters are involved but the outcomes do not rely on each other in the same 
way that they do in the other plays. The first plot, which in itself is almost a dual plot, involves Aeschynus'helping Ctesipho get possession of the mistress he wants, and likewlse involves Aeschynus' troubles in marrying the girl he loves. Aeschynus pretends that Bacchis is his mistress so that Ctesipho can enjoy her without being discovered by his father, Demea, who is a very strict old gentleman. of course, this deception complicates matters for Aeschynus too, and serves to bring out the characters of the two brothers, Demea and Micio, about whom the second plot revolves. This plot is concemed with showing the alfference in the interests of these two men. Miclo, unlike his brother, is a kind-hearted father who belleves that father and son should be on a mutual confidence basis. Each man carries to an extreme his theory of living and letting live, the one being too harsh, the other too lenient. Each profits by what he learns from the other. The climax of this plot comes when Demea turns the tables on Miclo and makes him play his own game.

In using this dual-plot method, Terence had to write connected stories, not just throw scenes 
together as Plautus did. It is this quality that makes his plays more interesting reading than those of Plautus. Terence did not have the same purpose In writing as his fellow playwright. It has already been noted that Plautus meant to entertain, and his idea of entertainment was joking. Terence's idea of humor was entirely different. He never interrupted the action of his plays to throw in a crude pun or joke. He relled on the unravelling of his plot to entertain his audience. He presented plays. Plautus presented what might correspond to the present day minstrels.

The development of his plays was much smoother than that of Plautus. The first thing that tended to bring about this smoothness was that the entrances and exits of his characters seemed natural. They did not appear to interrupt the action. Nor did he have someone to say that the door was opening because he had to get a different player on the stage. He led up to these appearances. In the Adelphi (lines $435 \mathrm{ff}$. ) Demea, alone on the stage, is talking of going back to the country. Just as he starts on his way, as though he looked down the road which he would follow, he says, 
- "Sed quis illic est, quem video procul?

estne Hegio?

Opperiar hominem hic, ut salutem et conloquar."

"But who is that I see at a distance?

Is it Hegio?

I shall wait here to greet him and talk with

This sollloquy makes the entrance of Hegio seem

natural. The words of Demea are not thrown in

with the abruptness of Plautus.

The same is true of his exits. In the same

play Aeschynus is trying to make a deal with the procurer, Sannio. He puts forth his proposition

and then says to Sannio (Iine 195-6),

"Nunc vide utrum $\nabla i s$, argentum accipere an causam meditare tuam.

Dellbera hoc, dum ego redeo, leno."

"Now decide whether you wish to receive the money or to consider your case.

Think about this until I return, procurer."

This is absolutely a natural exit, one in which

the actor can be plctured as being perfectly at ease.

In the case of Plautus we mentioned that he often had the improbable to happen. This is not so prevalent in Terence's works. There is one instance in Phormio where Chremes, the wife, and Demea are on the scene. Chremes has just learned 
that the girl Antipho married is the one he and Demlpho had planned for him--his daughter by the other woman. He gives hint after hint to Demipho so that his wife will not understand what they are talking about. In view of the fact that the two men had already discussed the marriage, it seems that Terence makes Demlpho appear rather dense. It is somewhat improbable that it would take the man so long to understand the situation.

Another improbablilty found in Terence is in Heautontimorumenos when he has clitipho, who has been desperately in love with Bacchis, marry a girl not even mentioned in the story until the boy's father suggests the marriage.

As a general thing, though, Terence manifests his understanding of life in such a way as to have the more probable action take place.

Plautus has been criticized in this paper for not making provision to overcome the difficulty of the stage convention of his day--that of having all the action take place on the street. Terence provides for this in a very fine way in Andria, (1. $483 \mathrm{ff.}$ ). From the street Lesbla is giving orders to someone within the house about caring for the baby. Simo 
overhears the conversation. It is a remark that he makes that shows Terence's dislike for such a stage convention. He makes simo act as if he thinks this is just a ruse of Davos to make him suppose that this woman has a baby by his son. By the answer he gives, Terence satirlzes the stage convention instead of yielding to it without complaint. In Iine 489 simo says,

"Non Imperabat coram, quid opus facto esset puerperae

Sed postquam egressat, 1llis quae suntintus clamat de via.

- Dave, itan contemnor abs te?"

"She did not order in their presence what was necessary to be done for the woman in confinement, but after she had come out, she cries from the street to those who are within. Oh Davus, am I thus deceived by you?"

Terence again differs from Plautus in that

he does not use Roman allusions. He has translated

Greek plays and he keeps them as Greek plays. Allusions to laws, customs, clties, etc., are all Greek.

Nelther does Terence adopt Plautus' hablt of addressing the audience throughout the play. He addresses the audience in the prologue and at the end of the play only. 
The skill that Terence shows in arranging for his actors to be where he wants them for the sake of carrying out his story quite exceeds that of Plautus. Thls difference may be illustrated by reference to the Adelphi, where he detains Demea in town by having him meet one of the farmhands who tells him that his son is not at the farm. It is hard to say how Plautus might have kept him in town when we remember that in Captivi he sends Philocrates back home and then questions others about the man he has sent away. The truth of the matter was that he wanted Philocrates to be the one to go home. But did he have to bungle up the affair then by questioning after he is gone and making the questioner seem so stupld?

All in all, concerning Terence's plots it might be said that he had very good ones which he developed consistently, thus making his play as good as the Greek original from which he copled it, If not better.

The technique in writing of these two men is another point of contrast. Plautus' style is rambling. He has his players speak line after line 
which gives no information really pertinent to the play. In the Captivi, it takes Ergasilius from line 778 to 873 to tell Heglo that his son is at the harbor--a b1t of information that he knew would delight the man more than anything else. Many other examples of the same thing could be clted from the plays of Plautus. Such a characteristic as this prevents his plays from being interesting reading. Perhaps the Roman people enfoyed listening to the ramblings of a parasite, but the public of today wants a story to move on.

Terence, however, is precise and to the point. We find such expressions as "Hulc 1llae lacrumae." "Hence those tears.", (Ine 126) in Andria. In Adelphi, (Iine 335) Sostrata has been crying because it seems that Aeschynus is being untrue to his mistress. The slave says,

"Era, lacrumae mittae ac potius quod ad hanc rem opus porro prospice."

"Mistress, omit the tears and rather look out for what needs to be done in this matter."

In Heautontimorumenos, (Iine 796) this crisp statement is found:

"lus summum saepe summast malitia."
"The greatest law is often the greatest injustice." 
Terence always sticks to the subject under discussion. He does not go off at a tangent, nor does he stop in the middle of a serious soliloquy for a pun, as his predecessor so often does. In Heautontimorumenos, (IInes 96-117) is a long speech in which Menedemus tells Chremes why his son went to Asia. In this speech, Menedemus sticks to what he started to say, explaining the situation very clearly to his friend.

One more example from this same play shows the clearness of his style. In line 77, we find, "Homo sum: humani n1l a me allenum puto." "I am a man. I think I am a stranger to
nothing human."

Can one learn a lesson from reading the plays of these two men? In the case of Plautus, any lesson that might be learned from the study of his works would not come from specific lines in his plays. The play would have to be taken as a whole, as in Miles Gloriosus. After reading this play, one would have the feeling that the captain got what he deserved. Thus the lesson derlved from the play would be to avold developing such characteristics as this braggart soldier had. No particular lesson could be learned from Aulularia, since even for 
the miser everything turned out well. His money was returned and his daughter was well married. And so in Menaechmi and the Captivi the case is the same. The fact that Plautus does not moralize in his plays brings us back to the point again that this man wrote purely for the entertainment of his public.

Terence, however, teaches lessons by means of his characters and the lines they speak. The Adelphi is especially a good play in this respect. Demea and Hicio are opposite types, Demea an exaggeration of the one, and Micio an exaggeration of the other. In this way each man is given an opportunity to tell the other what is wrong with his ph1losophy of IIfe and thus to profit by the other's mistakes. An excellent lesson can be learned from this play when Micio is telling on what basis he thinks father and son should be, (line 51-58)

"Do,praetermitto, non necesse habeo omnla Pro mec iure agere; postremo, al11 clanculum Patres quae faclunt, quae fert adulescentia, Ea ne me celet consuefeci filium. Nam qui mentiri aut fallere insuerit patrem, Audacter tanto magis audebit ceteros. Pudore et liberalitate liberos Retinere satius esse credo quam metu." 
"I give, I overlook, I do not consider it necessary to rule everything by my authority. What youth suggests and some do unknown to their fathers, my son is not accustomed to hide from me. For he who has made it a practice to lie and decelve his father, so much more boldly will he dare do the same to others. I belleve it better to restrain children through shame and freedom than through fear."

This is a good piece of advice and if it is not carried to extreme would prove an excellent way for fathers to gain the confidence of their sons.

Again in the same play (IIne 831-834),

n

O noster Demea

Ad omnia alia aetate sapimus rectius;

Solum unum hoc vitium adfert senectus homintbus;

Adtentlores sumus ad rem omnem, quam sat est."

"Oh, my Demea, we become wiser with age in everything else; only this vice does old age bring to men: we are more attentive to our own interests than is necessary."

How true this is! The happlest people are those who think not so much of themselves but of others.

In Heautontimorumenos, Chremes is telling

Menedemus that the trouble between $\mathrm{h} / \mathrm{m}$ and $\mathrm{hls}$ son lies in that they do not live on a basis of mutual confidence and understanding, that the boy no doubt was a good son, and the father a loving one, but that the two did not understand each other. Lack of understanding today is the source of much trouble, 
and so again we could learn a lesson from these Iines of Terence, (Iine 154-157)

" Hoc quod fit, ubi non vere vivitur. Tu 1llum numquam ostendisti quandi penderes, Nec tibi 1llest credere ausus quae est aequam patri.

Quod s1 esset factum, haec numquam evenisset tibi."

" and that is what happens when people are not living on terms of sincerity. You have never shown him how much you value him, nor has he dared to confide in you what is due a father. If this had been done, this misfortune would never have come to jou."

In Phomio, in one concise line, (11ne 794)

"vir viro quid praestat!", Terence expresses his vlew of mankind--"what a difference there is in men!"

From these illustrations it is possible to understand something of the man Terence. He was young himself and looked at life as youth does, as can be realized from the parts he has the young men play in the Adelphi. Still his philosophy was good. It may be summed up in the sentence--

"Homo sum: humani nil a me allenum puto."

on the whole, however, drama does not require a moral.

It hes already been stated that many of the characters in Plautus and Terence are stock characters. If the different types found in these 
elght plays under study were to be I1sted, not more than ten would be found. Some may be individualized a little more than others, and a few individual characters are introduced.

First, looking back over the plays of Plautus, there are two characters which come to mind as distinct indivualistic characters not found elsewhere in the plays of Plautus. These are the braggart soldier in Miles Gloriosus and Euclio the miser, in Aulularia. In the four plays of Plautus covered in this study these are the only two who advance from the ranks of mere types. Of course, they, too, represent a certain kind of man, but the way in which they are handled in their respective plays makes them individuals. Mr. W. H. Juniper of Ohio State University, in an article published in the February, 1936, issue of the Classical Journal, suggests that Plautus individualized his characters only when the plot 1 depended upon that character. This statement can readily be accepted since in the case of both Pyrogpolynices, the braggart soldier, and Fuclio,

1. Juniper, Walter H., "Character Portrayal in Plautus," Classical Journal XXXI(1936),p.278. 
the play is built around the character. Plautus adopts two methods of bringing out these characters aside from the description he always gives in the prologues. First he has other players talk about them, giving the audience a good idea of what to expect. Then he has the character act in such a way that the characteristics mentioned are emphasized. In the case of Miles Glorlosus, the entire first act is devoted to giving the audience a true picture of this captain. This is done by the captain himself bragging and by the parasite flattering him, always having asides to the audience to further accentuate the man's boastful att1tude. Throughout the play allusions are made to the gotism of the captain. Then in lines 947-986, Palestrio, his servant, easily persuades him to leave his mistress, who has fallen in love with another man and has planned this method for her to escape, and to favor the other woman who, Palestrio says, is so desperately In love with him. Flattery is the weapon used to bring about the results desired by Palestrio. This is as good a character study as can be found anywhere. The same is true of Exclio in Aulularia. 
Flrst he explains in the prologue how miserly Euclio is by referring to his father and grandfather who were misers before him. Next he has Eucllo act the part by his constant ramblings about the door being securely locked and by his admonitions to his daughter not to admit anyone to the house while he is away. He brings out this miserliness very well in the scene where Megadorus asks for the daughter's hand in marriage. Euclio thinks that Megadorus suspects he has money, and for that reason wants to marry the girl. His frequent repetition that he is penniless throws even more light upon his character. The comments of other characters also show his greed, as in line 206, where Megadorus says,

"neque 1110 quisquam est alter hodie ex paupertate parcior."

"There is no other today more frugal from poverty than that man."

In the scene already mentioned where Lycides is talking about the daughter, and Euclio about his gold, Plautus gives an excellent characterization of the old man. Any father more interested in his money than in the welfare of his own child is truly a miser. 
We have, then, these two characters in Plautus who rise above the average. That can be sald for his other characters? They never really become individualized. He emphasizes some a little more than others for the sake of humor, usually. He always rather exaggerates the parts of the farasites because he feels that that will bring laughs from his audience, but as far as creating individuals, that ends in these four plays with Pyrogpolynices and Euclio.

With Terence we find a quite different story. His characteristic knowledge of human nature aids him in creating characters with traits which make individuals of them. It is true that he uses stock characters, but it is equally true that he individualizes a number of these stock characters. The best characters he draws are Demea and Micio in the Adelphi. The two are vividly portrayed because of the contrast he draws between them. They are absolutely opposites and Terence uses many opportunities to bring out this point. Micio is a kindhearted, lenient, trusting man, who places the greatest confidence in his son. He has lived an 
easy life himself and desires the boy to do the same. Demea, on the other hand, is the sort of person who places a great deal of confidence in no one. This is shown by his suspicion of his son shortly after he has boasted about rearing him to be a real man with high morals and a great dislike for anything wrong. Demea cannot be looked upon as a mean man, but as one who somowhat forgets what it means to be young. The fact that Terence has Demea live in the country and Micio in town helps in the contrast of these characters, because it aids us in picturing Micio as the man about town and Demea as a man who looks askance at the things his brother does. The effect each has on his boy is further characterization of the men. Aeschinus, ward of Miclo, is courageous and unafraid to stand up for his own rights. Ctesipho, son of Demea, is a very different type. He has to shove all responsibility for his wrongs upon Aeschinus, showing that he has not been permitted to live his own life. Demea did not love Ctesipho less than Micio did Aeschinus, but it was Demea's bellef that it was not good to let children know how much they were loved, while Micio felt 
that they should know. The very way he reproves Aeschynus for his wrong (lines 638-96) bespeaks his love for the boy.

Alt hough these two are Terence's best characterizations in the four plays, they are not his only ones. I shall mention others but shall not go into detail concerning them as I did with Demea and Micio. In Phormio, the parasite, Phormio, rises above the part of a typical parasite. He is much more of an individual than Ergasilius, for instance, in Plautus' Captivi. Ergasilius, in true parasite fashion, speaks constantly of eating. Phormio is interested in food but he goes farther. He shows a disposition that is not very likeable, a spiteful disposition, from which, although he is hurting his benefactors, he derives pleasure. He is out to care for Phormio first, last, and always. This is shown when he spites Chremes by telling his wife that he is a bigamist, and then realizing that he will receive no more help from this man, says,

"Enimvero, prius quam haec dat ventam, mihi prospictam."

"Before she grants pardon, I shall look out for mỳself." 
The picture of Menedemus, in Heautontimorumenos, as a martyr for his son after he realizes that he has driven him away is rather plainly drawn. He is so anxious to have his son back with him that he is willing to do anything for him.

In concluding this discussion of Rome's two greatest comedy writers, a characteristic statement might be given about each.

Plautus, the cholce of the Romans, wrote for the people, with his main purpose of entertalning this public foremost in his mind at all times. Although his plays were preferred by the people of his day, they are not preferred today, because he did not seem to possess a very deep understanding of human nature or of dramatic plot development.

Terence wrote plays which still have an appeal to people. His basic idea, showing an understanding of human nature can be expressed in the quotation already given, "humani nil a me alienum puto." "I think I am a stranger to nothing human." 


\section{BIBLIOGRAPHY}

Books

Capps, Edward, "Greek Comedy", Greek LiteratureA Series of Lectures Delivered at Columbia University New York, The Columbla University Press, 1912.

Collins, William L., Plautus and Terence, Philadelphia, J. B. Lippincott \& Co., 1873.

Flickinger, Roy C., The Greek Theater and Its Drama,

Chicago, University of Chicago Press, 1918.

Haigh, A. E., The Tragic Drama of the Greeks,

London, Oxford University Press, 1925.

Hamilton, Edith, The Roman Way, New York, W. W. Norton \& Co., 1932 .

Norwood, Glibert, Plautus and Terence, New York, Longmans, Green \& Co., 1900.

Patterson, J. L., The Cyclops of Euripides, New York, The Macmilian Co., 1900.

Plautus, Titus Maccus, Aulularia, London, Oxford University Press, 1933.

Plautus, Titus Maccus, Captivi, London, Oxford University Press, 1926.

Plautus, Titus Maccus, Menaechmi, London, Oxford University Press, 1929.

Plautus, Titus Maccus, Miles Gloriosus, London, Macmillan \& Co., 1927 .

simcox, G. A., Latin Iiterature, History and Criticism, Vol. I, New York, Harper \& Brothers, 1883.

Terence, Publius, Adelphoe, London, Macmillan and Company, 1928.

Terence, Publius, Andria, London, Oxford University Press, 1923. 
Terence, Publius, Hautontimorumenos, London, Macmilian \& Company, 1924.

Terence, Publius, Phomio, London, Oxford University Press, 1926.

Periodicals

Juniper, Walter H., "Character Portrayal in

Plautus", The Classical Journal 31:276-88, February, 1936. 